\title{
Exercise, Energy Intake, Glucose Homeostasis, and the Brain
}

\author{
๑Henriette van Praag, ${ }^{1}$ Monika Fleshner, ${ }^{2}{ }^{-}$Michael W. Schwartz, ${ }^{3}$ and Mark P. Mattson ${ }^{4,5}$ \\ ${ }^{1}$ Neuroplasticity and Behavior Unit, Laboratory of Neurosciences, National Institute on Aging, Baltimore, Maryland 21224, ${ }^{2}$ Department of Integrative \\ Physiology and the Center for Neuroscience, University of Colorado, Boulder, Colorado 80309, ${ }^{3}$ Diabetes and Obesity Center of Excellence, University of \\ Washington, Seattle, Washington 98195, ${ }^{4}$ Cellular and Molecular Neuroscience Section, Laboratory of Neurosciences, National Institute on Aging, \\ Baltimore, Maryland 21224, and ${ }^{5}$ Department of Neuroscience, Johns Hopkins University School of Medicine, Baltimore, Maryland 21205
}

Here we summarize topics covered in an SFN symposium that considered how and why exercise and energy intake affect neuroplasticity and, conversely, how the brain regulates peripheral energy metabolism. This article is not a comprehensive review of the subject, but rather a view of how the authors' findings fit into a broader context. Emerging findings elucidate cellular and molecular mechanisms by which exercise and energy intake modify the plasticity of neural circuits in ways that affect brain health. By enhancing neurogenesis, synaptic plasticity and neuronal stress robustness, exercise and intermittent energy restriction/fasting may optimize brain function and forestall metabolic and neurodegenerative diseases. Moreover, brain-centered glucoregulatory and immunomodulating systems that mediate peripheral health benefits of intermittent energetic challenges have recently been described. A better understanding of adaptive neural response pathways activated by energetic challenges will enable the development and optimization of interventions to reduce the burden of disease in our communities.

\section{Introduction}

Regular aerobic exercise and moderation in energy intake promote health and reduce the risk of several major diseases, including diabetes, cardiovascular disease, stroke, and cancers. The rapid increase in the incidence of obesity, diabetes, and associated diseases during only the past few generations is attributed mostly to excessive consumption of high energy density processed foods combined with sedentary lifestyles (Philippas and Lo, 2005; PiSunyer, 2009). Regular aerobic exercise has beneficial effects on the brain, including improving mood and cognitive function, and intermittent energy restriction (IER)/fasting may have generally similar positive effects on brain function (Mattson, 2012). Less appreciated is evidence that the brain plays fundamental roles in regulating peripheral glucose metabolism by pathways and signaling mechanisms that are beginning to be understood (Schwartz et al., 2013). In turn, circulating factors produced by peripheral tissues in response to exercise and IER may stimulate neuroplasticity and cellular stress resistance in the brain. Recent findings described in this Symposium provide a window into the molecular and cellular mechanisms by which exercise and IERs bolster brainpower, protect neurons against injury and neurodegenerative disorders, and improve systemic energy metabolism and function of the autonomic nervous system.

\footnotetext{
Received July 10, 2014; revised Aug. 27, 2014; accepted Sept. 3, 2014.

This work was supported by the Intramural Research Program of the National Institute on Aging to H.v.P. and M.P.M., and National Institute of Diabetes and Digestive and Kidney Diseases Grants DK090320, DK083042, and DK052989 to M.W.S. We thank Ruiqian Wan for providing sample recordings of home cage activity and heart rate in rats on control and intermittent fasting diets, and David Creer for photomicrograph composition.

The authors declare no competing financial interests.

Correspondence should be addressed to Dr. Mark P. Mattson, Cellular and Molecular Neuroscience Section, Laboratory of Neurosciences, National Institute on Aging, 251 Bayview Blvd, Baltimore, MD 21224. E-mail: mark.mattson@nih.gov.

DOI:10.1523/JNEUROSCI.2814-14.2014

Copyright $\odot 2014$ the authors $\quad 0270-6474 / 14 / 3415139-11 \$ 15.00 / 0$
}

As with other animals, a major driving force for the evolution of the human brain was the need to acquire the resources necessary for survival and propagation of the species, including food, mates, and shelter. Those individuals whose brains functioned best during periods of resource scarcity would be the most successful in meeting the challenges. From an evolutionary perspective, intermittent running and food deprivation (involuntary fasting) have been the most common energetic challenges our brains and bodies experience (Bramble and Lieberman, 2004; Longo and Mattson, 2014). During sustained exercise and fasting, it is critical that energy reserves be managed efficiently so as to provide both peripheral tissues (particularly muscles) and the brain with sufficient energy to survive and thrive. We therefore focus on the results of studies of the effects of running and IER on brain function and robustness (stress resistance and resiliency), and on systemic energy metabolism. The ways in which intermittent energetic challenges enhance stress resistance and forestall disorders promoted by chronic stress (e.g., anxiety, depression, and cardiovascular disease) will be described. Among such mechanisms are improved cellular bioenergetics, repair or removal of oxidatively damaged molecules, and reduced inflammation (Fig. 1).

Molecular profiling studies show that most, if not all, brain regions are affected by aerobic exercise and dietary energy restriction, with changes in the expression of genes encoding proteins involved in synaptic plasticity, neurotrophic factor signaling, cellular bioenergetics, disposal of damaged proteins and organelles, and cellular stress resistance (Tong et al., 2001; Kuhla et al., 2007; $\mathrm{Xu}$ et al., 2007; Alirezaei et al., 2010; Stranahan et al., 2010). Intermittent energetic challenges can also change the structure of neuronal circuits by, for example, stimulating neurogenesis, neurite outgrowth, and synapse formation (Voss et al., 2013). Although the signaling pathways that mediate such adaptive re- 


\section{Exercise}

Neurogenesis
Synaptogenesis
Synaptic plasticity
Cognitive function
Motor function
DNA repair
Mitochondrial biogenesis
Reduced inflammation

Decreased resting heart rate Increased heart rate variability Decreased blood pressure

Increased insulin sensitivity Ketone body production

Increased insulin sensitivity

Fatty acid mobilization Reduced inflammation

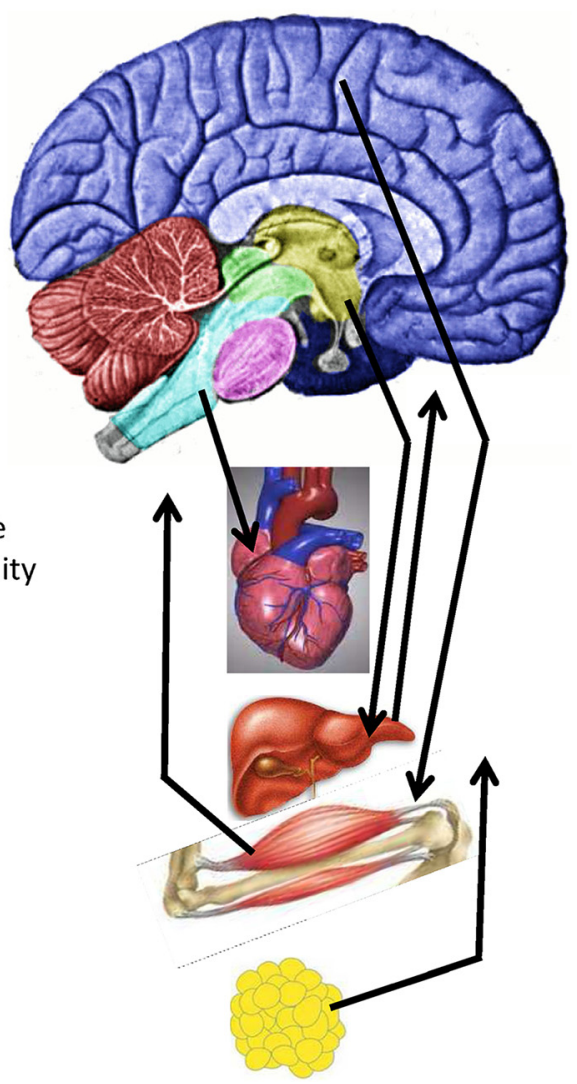

Intermittent Fasting

Neurogenesis

Synaptogenesis

Synaptic plasticity

Cognitive function

Motor function

Reduced inflammation

Enhanced autophagy

Decreased resting heart rate

Increased heart rate variability

Decreased blood pressure

Increased insulin sensitivity

Ketone body production

Increased insulin sensitivity

Fatty acid mobilization

Reduced inflammation

Figure 1. Exercise and IER/fasting exert complex integrated adaptive responses in the brain and peripheral tissues involved in energy metabolism. As described in the text, both exercise and IER enhance neuroplasticity and resistance of the brain to injury and disease. Some of the effects of exercise and IER on peripheral organs are mediated by the brain, including increased parasympathetic regulation of heart rate and increased insulin sensitivity of liver and muscle cells. In turn, peripheral tissues may respond to exercise and IER by producing factors that bolster neuronal bioenergetics and brain function. Examples include the following: mobilization of fatty acids in adipose cells and production of ketone bodies in the liver; production of muscle-derived neuroactive factors, such as irisin; and production of as yet unidentified neuroprotective "preconditioning factors" (Dezfulian et al., 2013). Suppression of local inflammation in tissues throughout the body and the nervous system likely contributes to prevention and reversal of many different chronic disease processes.

sponses are undoubtedly complex, BDNF has been shown to play particularly prominent roles (Marosi and Mattson, 2014). For example, BDNF can stimulate mitochondrial biogenesis to improve neuronal bioenergetics and enable synapse formation and maintenance in the brain (Cheng et al., 2012), and can stimulate DNA repair in neurons (Yang et al., 2014). Interestingly, administration of BDNF into the brain increases peripheral insulin sensitivity (Nakagawa et al., 2000) and parasympathetic tone (Wan et al., 2014), thereby improving glucose metabolism and cardiovascular function. We therefore highlight BDNF signaling as playing a key role in the integration of CNS neuronal networks with peripheral neuroendocrine pathways that mediate adaptive responses to energetic challenges.

\section{Exercise, endurance factors, neurogenesis, and spatial} pattern separation

Basic research in animals has shown that exercise affects multiple brain areas and systems. The underlying central mechanisms that have been investigated include neurotransmitters, neurotrophins, fine neuronal morphology, angiogenesis, and hippocampal neurogenesis (van Praag, 2008). More recently, the peripheral triggers that may lead to the benefits of exercise for brain function have begun to be researched. In particular, the possibility that skeletal muscle activation by exercise or pharmacological agents underlies cognitive effects of aerobic activity became of interest with the identification of transcriptional factors regulating muscle fiber contractile and metabolic genes (Wang et al., 2004). The peroxisome proliferator activated receptor $\delta(\operatorname{PPAR} \delta)$ is a transcription factor that regulates fast-twitch muscle fiber contraction and metabolism. PPAR $\delta$ overexpression increased oxidative muscle fiber number, and administration of the selective agonist GW501516 increased endurance when combined with training (Narkar et al., 2008). PPAR $\delta$ is controlled by the AMP-activated protein kinase (AMPK), a master metabolic regulator important for glucose homeostasis, appetite, and exercise physiology (Hardie, 2004). AMPK agonist 5-aminoimidazole-4-carboxamide riboside (AICAR) administration enhanced running endurance by $45 \%$ in sedentary mice (Narkar et al., 2008). Subsequently, we tested whether pharmacological activation of skeletal muscle induces cognitive effects comparable with exercise. Our studies suggest that AICAR treatment can enhance spatial learning and hippocampal neurogenesis in young mice (Kobilo et al., 2011a). Moreover, in old mice, AICAR administration elevates expression of genes important for energy metabolism in both muscle and the hippocampus. In addition, synaptic plasticity genes in the hippocampus are enriched, and spatial memory in the Morris water maze (Morris et al., 1982) is enhanced by AICAR in aged female mice (Kobilo et al., 2014).

The above studies suggest that brain plasticity is maintained throughout the lifespan and that it can be enhanced by exercise and other interventions that activate AMPK. An important structural process therein is the genesis of new neurons in the dentate gyrus (DG) of the hippocampus in the adult brain (Taupin, 2007). Running increases new DG neuron number in rodents 


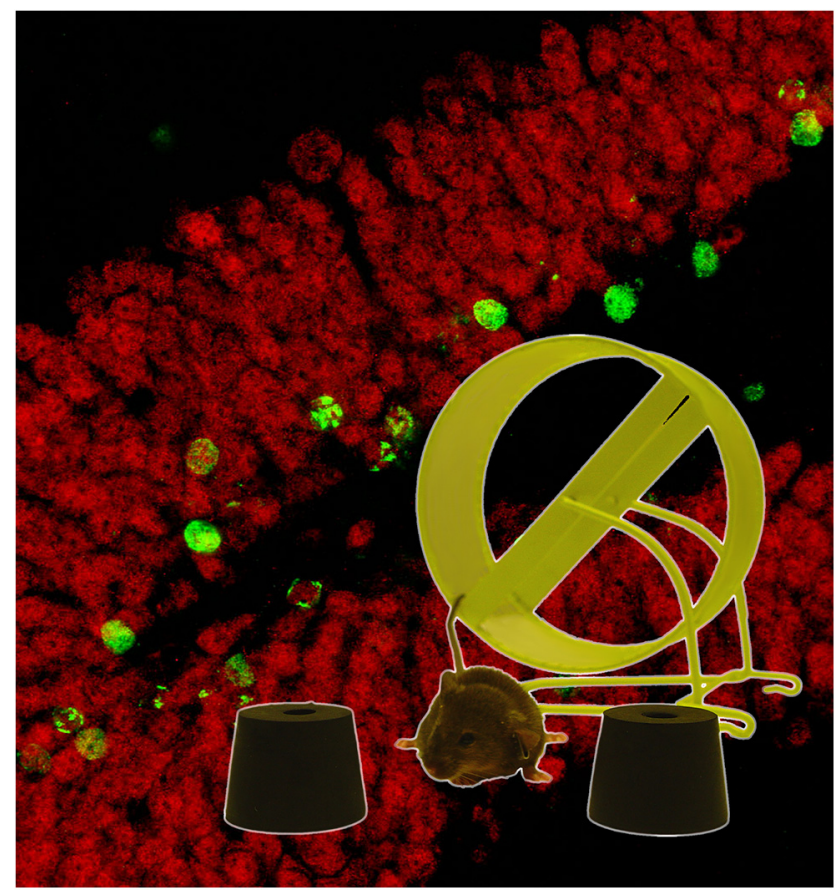

Figure 2. Running enhances adult hippocampal neurogenesis and the ability of a mouse to discriminate between two adjacent identical stimuli, enabling pattern separation. Coronal section through the mouse DG was immunofluorescent double-labeled for BrdU (green) and the neuronal marker NeuN (red).

(van Praag, 2008). Indeed, physical activity, rather than cognitive stimulation, is required for the production of new hippocampal neurons (Kobilo et al., 2011b; Mustroph et al., 2012; Grégoire et al., 2014). This effect is associated with BDNF induction, a neurotrophin that is known to be strongly upregulated in the hippocampus by exercise (Neeper et al., 1995; Marosi and Mattson, 2013) and that, in turn, appears to be important for new neuron survival and function (Bekinschtein et al., 2011; Vivar et al., 2013). Consistent with this hypothesis, selective ablation of the high-affinity BDNF receptor TrkB in progenitor cells abolishes running-induced neurogenesis (Li et al., 2008). Enhanced neurogenesis is associated with improved cognition, whereas a decline in new neuron number is linked to aging and depression. Indeed, in rodents, exercise improves synaptic plasticity and spatial memory (van Praag, 2008). Ablation of adult neurogenesis abolishes the running-induced cognitive enhancement in the Morris water maze (Clark et al., 2008).

To better understand the precise functional role of adult neurogenesis, it is essential to delineate the neural circuitry in which the cells reside. The DG is part of the so-called "trisynaptic circuit." Information is considered to be processed from entorhinal cortex to DG, DG to area CA3 pyramidal cells, and from area CA3 to CA1 pyramidal cells to be ultimately stored in cortex (Amaral and Witter, 1989). Each of these regions has specific cell types and plasticity that contribute to learning and memory. The neurogenic DG and, to some extent, area CA3 are deemed important for pattern separation, or the differential storage of highly similar stimuli and experiences (Marr, 1971). Reduction of adult neurogenesis impairs pattern separation (Clelland et al., 2009), whereas, conversely, running improves the animal's ability to distinguish between closely related objects or events (Creer et al., 2010). The hypothesis that the observed improvement in fine spatial distinctions involves exercise-induced increase in adult neurogenesis (Fig. 2) is supported by findings from a transgenic mouse with enhanced adult hippocampal neurogenesis. These mice are characterized by improved differentiation between overlapping contextual representations, indicative of enhanced pattern separation (Sahay et al., 2011).

To obtain a more comprehensive insight as to how exercise-induced neurogenesis enhances pattern separation, we recently set out to map the specific inputs to adult born neurons using a combination of retroviral- and rabies virusbased methods (Vivar et al., 2012). We observed that, under sedentary conditions, newly born neurons receive sequential direct innervation from structures important for memory formation and function, but not from brain areas considered relevant to stress, motivation, and motor behavior, such as the amygdala and striatum. Initially, a local circuit of septal-hippocampal cells provides input to new neurons, including transient innervation from mature dentate granule neurons as well as direct feedback from area CA3 pyramidal neurons. Subsequently, entorhinal cortical regions deemed relevant to integration of sensory and environmental information provide innervation to new neurons. Removal of this input by excitotoxic lesions caused spatial pattern separation deficits (Vivar et al., 2012). Determining how exercise influences the development and quantity of both local and long range projections to new neurons is an important priority for future studies.

\section{Exercise and stress robustness}

The body and brain respond to exercise in ways that enhance the functionality and stress resistance of many organ systems. Exposure to acute stressors evokes a highly adaptive integrated physiological response that functions to facilitate fight/flight responses and promote survival in the face of challenges. The acute stress response dilates the pupils, increases heart rate and respiration, increases circulating glucocorticoid, catecholamine, and glucose levels to facilitate energy mobilization into brain and other tissues and optimize blood flow to muscle, elevates inflammatory cytokines and chemokines, and primes innate immunity to better respond to injury. If the stress response, however, is repeatedly or chronically activated, or the stressors are excessive and severe, the brain/mind and body can be adversely affected (Thompson et al., 2014). Regular physical activity, in contrast, is broadly beneficial for both brain/mind and body. One important benefit of regular physical activity is increased stress robustness. There is evidence from human and animal studies that a sedentary lifestyle is associated with stress vulnerability, whereas a physically active lifestyle is associated with stress robustness (Brown and Siegel, 1988; Fleshner et al., 2011; Boschloo et al., 2014). Stress robustness is a state of both stress resistance (capable of enduring severe and/or chronic stressors before experiencing negative consequences) and stress resilience (ability to rapidly recover after experiencing negative consequences).

Laboratory rodents housed with a running wheel will run considerable distances, typically $5-15 \mathrm{~km}$ during a $12 \mathrm{~h}$ dark (active) period. Wheel running appears to be a natural rodent behavior, as mice and rats in the wild will choose to run on wheels (Meijer and Robbers, 2014). Wheel running is rewarding; rats will display conditioned place preference associated with wheel running and activation of brain reward pathways (Lett et al., 2000, 2001; Foley and Fleshner, 2008; Greenwood et al., 2011). And wheel running produces metabolic improvements, including increased fitness (Kennedy et al., 2005) and decreased abdominal adiposity (Speaker et al., 2014).

Wheel running reliably produces stress robustness in rodents. Insight into neural and physiological mechanisms of stress ro- 
bustness has come from rodent models that involve running wheel exercise and a titratable stressor ( $5 \mathrm{~s}, 1.5 \mathrm{~mA}$ unpredictable, inescapable tail shock). The negative consequences of exposure to inescapable shock that are mitigated by wheel running include increases of anxiety/depression (Moraska and Fleshner, 2001; Greenwood et al., 2003b, 2005, 2012a; Greenwood and Fleshner, 2008), learning impairments (Greenwood et al., 2003b; Greenwood and Fleshner, 2008), excessive activation of the sympathetic nervous system (Greenwood et al., 2003a; Fleshner, 2005), antigen-specific immunosuppression (Fleshner, 2000, 2005; Moraska and Fleshner, 2001), and adipose inflammation (Speaker et al., 2014). Additionally, wheel running facilitates the recovery of stress-evoked disruptions in diurnal rhythms of physiology and sleep architecture (Fleshner et al., 2013; R.S. Thompson and M.F., unpublished observations), improves corticosterone response habituation (Sasse et al., 2008), and elicits plasticity in serotonergic, noradrenergic, and dopaminergic stress-responsive brain circuitry (Greenwood et al., 2003b, 2012b; Greenwood and Fleshner, 2011; Loughridge et al., 2013). Finally, wheel running shifts the stressor response threshold, such that physically active rats have little or no stress response (corticosterone) to lower intensity stressors, but equal or greater corticosterone responses to high intensity stressors (Campeau et al., 2010; Speaker et al., 2014).

Each of these effects of exercise on stress physiology and behavior is mediated by unique adaptations in brain circuitry and peripheral tissues. For example, progress has been made in understanding the neural and physiological mechanism by which physical activity protects animals from the negative cognitive and emotional consequences of inescapable stress (IS). For these outcomes, the primary neural adaptation involves central serotonergic (5HT) stress-responsive circuits (Fig. 3). We have reported that habitual wheel running (6 weeks) is sufficient both to produce changes in dorsal raphe nucleus (DRN) 5HT neuronal activation and to prevent learned helplessness behaviors (i.e., reduced social exploration, exaggerated fear, and shuttle box escape) tested $24 \mathrm{~h}$ after exposure to IS (Greenwood et al., 2003b, 2005). Through a series of studies, we have established that wheel running increases the expression of 5HT1A inhibitory autoreceptors in the DRN (Day et al., 2004; Loughridge et al., 2013) and decreases activation of DRN 5HT neurons during inescapable stress (Greenwood et al., 2003b). This results in constraint of DRN 5HT activation and release of 5HT to DRN projection sites (i.e., amygdale) (Amat et al., 1998) and dorsal striatum (P. J. Clark and M.F., unpublished observations).

Wheel running also produces changes in postsynaptic $5 \mathrm{HT} 2 \mathrm{C}$ receptor expression in DRN projection sites (amygdala and dorsal striatum) (Greenwood et al., 2012b). This is important because 5HT2C in dorsal striatum and amygdala are involved in the expression of learned helplessness behaviors (Strong et al., 2009, 2011). In total, the changes produced by wheel running serve to constrain the excessive DRN 5HT response to IS. This change, in addition to the downregulation in 5HT2C receptor expression in amygdala and dorsal striatum, would dampen 5HT signaling and prevent neuronal sensitization of this circuit produced by IS.

Maier and Watkins (2010) have reported that inescapable shock, but not controllable tail shock, produces neuronal sensitization of 5HT circuits and learned helplessness behaviors. Similar to the effect of exercise, controllable tail shock also constrains activation of this circuit; however, instead of upregulation of 5HT1A, the constraint produced by controllable stress is due primarily to increased inhibitory input to the DRN from the medial prefrontal cortex (Amat et al., 2005, 2006; Baratta et al., 2008). Interestingly, stress robustness conferred by wheel running does not depend on this constraint pathway because lesioning the medial prefrontal cortex does not prevent the protective effect of wheel running on learned helplessness behaviors (Greenwood et al., 2013). Thus, regular physical activity produces changes in 5HT stress-responsive circuits that constrain the response during inescapable shock and prevent the cognitive (shuttle box escape deficits) and emotional (reduced social exploration and exaggerated fear) negative consequences of IS. Evidence suggests that BDNF mediates anxiolytic and antidepressant effects of exercise and antidepressant drugs in animal models (Duman et al., 2008; Licznerski and Duman, 2013). It will therefore be of interest to determine if and how BDNF signaling influences serotonergic signaling, and vice-versa, in stress-responsive neuronal circuits.

Physical activity, therefore, produces numerous changes in the brain and the periphery that converge to promote stress robustness. In general, regular exercise promotes stress response efficiency. The stress response is physiologically powerful and energy demanding, and a host of neuroendocrine responses have evolved to meet this energy demand. Physically active animals are able to constrain responses to mild stressors for which a major response is unnecessary and rapidly return physiological functioning to baseline when a stress response is required. These types of adaptations improve stress robustness and allow an organism to minimize the energy costs and other negative consequences of repeated, chronic, or excessive stress responses on mind/brain and body. 


\section{The brain-centered glucoregulatory system}

Exercise and dietary energy restriction can both improve energy metabolism by increasing insulin sensitivity (O'Neill, 2013; Longo and Mattson, 2014), but whether the brain participates in these and other crucial aspects of glucose homeostasis is an important unanswered question. Pancreatic islets clearly play a central role in the control of glucose homeostasis. When plasma glucose levels rise after a meal, the associated increase of insulin secretion and action on key target tissues exerts a potent glucose-lowering effect, both by inhibiting hepatic glucose production and by increasing tissue glucose uptake. When food is unavailable, islet hormones again play a critical role to defend glucose homeostasis: falling plasma glucose levels inhibit insulin secretion while enhancing the release of glucagon, a combination that increases hepatic glucose production and prevents plasma glucose levels from dropping out of the normal range. These fundamental observations, combined with evidence that diabetes pathogenesis involves impairments of both insulin secretion and insulin action, lay the foundation for our current islet-centered view of glucose homeostasis. The clinical translation of this understanding has had an enormous impact on drug development for the treatment of diabetes, which currently revolves around administration of either insulin itself or drugs that enhance its secretion or action (Kahn et al., 2014).

That the brain is capable of influencing glucose homeostasis was first established some 160 years ago by the pioneering work of Claude Bernard (Bernard, 1854), but the brain is not widely seen as playing a role in either day-to-day blood sugar control or diabetes pathogenesis (Kahn et al., 2014). To the extent that the brain does play a role, many view it as one that is likely secondary to the role played by islets. Yet a growing literature has begun to challenge this view (Schwartz et al., 2013) based on evidence that: (1) in normal animals, the contribution of insulin-independent mechanisms (termed "glucose effectiveness") to glucose homeostasis is comparable with that made by insulin (Best et al., 1996); (2) the brain can rapidly improve glucose intolerance in obese mice by potently and selectively increasing glucose effectiveness, with no effect on either insulin secretion or action (Morton et al., 2013); (3) the brain can normalize hyperglycemia and associated neuroendocrine derangements in animals with severe insulindeficient diabetes (German et al., 2011); and (4) in addition to the direct action of insulin on the liver, insulin and nutrients can inhibit hepatic glucose production via an indirect pathway (Lu et al., 2012).

We recently synthesized these observations into a physiological perspective of how islet- and brain-centered glucoregulatory systems (BCGSs) interact to control glucose homeostasis (Schwartz et al., 2013). After a meal, both brainand islet-centered regulatory systems are proposed to participate in adaptive responses that restore glucose homeostasis. The absorption of ingested nutrients into the circulation stimulates insulin secretion and this response, through the actions of insulin in muscle, fat, and liver, promotes glucose disposal while inhibiting glucose production. At the same time, insulin-independent mechanisms are recruited in part via activation of the BCGS. Like the action of insulin, these insulinindependent effects promote glucose disposal (e.g., through increased liver glucose uptake, which is a major determinant of postprandial glucose disposal and is largely insulinindependent) while simultaneously inhibiting glucose production. This two-system model therefore incorporates both insulin-dependent and insulin-independent mechanisms to promote the return of increased plasma glucose levels to basal values after a meal. In the fasted state, islet-BCGS interactions are similarly implicated in the increase of hepatic glucose production and decrease of tissue glucose uptake that maintains circulating glucose concentrations in the normal range.

Relevant to these considerations is the observation that, when the adipocyte hormone leptin is administered at low doses into the brain of rats or mice with uncontrolled, insulindeficient diabetes, pronounced hyperglycemia is completely normalized despite persistent, severe insulin deficiency (da Silva et al., 2006; German et al., 2011). From this observation, we infer that BCGS activation can remedy diabetic hyperglycemia by, in effect, compensating for severe insulin deficiency. Extending this reasoning, it follows that dysfunction of both pancreatic islets and the BCGS may be required for diabetes to occur (Schwartz et al., 2013), and available evidence suggests that diabetes and BCGS dysfunction are linked tightly to one another. For one, normal BCGS function requires input to the CNS from both insulin and leptin, and states of insulin deficiency trigger leptin deficiency as well (Havel et al., 1998). Further, hypothalamic injury and gliosis occur in rodent models of obesity and Type 2 diabetes (Posey et al., 2009; Horvath et al., 2010; Cai, 2012; Milanski et al., 2012; Thaler et al., 2012), raising the possibility that defective BCGS function contributes to diabetes pathogenesis in obese individuals.

Recent work has begun to extend these observations to the question of how exercise affects glucose homeostasis. In rodent models of diet-induced obesity, for example, exercise training can prevent hypothalamic inflammation and associated resistance to leptin and insulin (Krawczewski Carhuatanta et al., 2011; Chiarreotto-Ropelle et al., 2013). These observations raise the possibility that improved BCGS function contributes to the beneficial effects of exercise on glucose homeostasis, and additional studies are warranted to evaluate this possibility. In addition, BDNF signaling in the brain, which is known to be upregulated by exercise, can enhance peripheral insulin-mediated glucose uptake (Nakagawa et al., 2000). It is therefore important to understand if and how specific components of the BCGS are regulated by BDNF.

\section{Intermittent energy restriction/fasting and optimal brain health}

Metabolic adaptations to food deprivation are highly conserved and ensure a constant supply of energy substrates to neurons while also stimulating signaling pathways that bolster stress resistance. IER refers to eating patterns that include extended time periods during which little or no food is consumed (typically 16-24 h) interspersed with periods of ad libitum eating. Rats and mice on an IER (alternate day fasting) diet live up to $30 \%$ longer and exhibit improved overall health as indicated by less accumulation of abdominal fat, increased insulin sensitivity, reduced blood pressure and heart rate, and a lower incidence of tumors (for review, see Longo and Mattson, 2014). Physiological changes that occur during fasting are highly conserved in rodents and humans. Upon depletion of liver glycogen stores (typically within 12-16 h of the last meal), fatty acids are mobilized from adipose cells and are metabolized by liver cells to produce ketone bodies ( $\beta$ hydroxybutyrate and acetoacetate), which are released into the blood and used as an energy source by cells throughout the body and brain. Moreover, ketones have recently been shown to have neuroprotective signaling functions that involve inhi- 
bition of histone deacetylases (Shimazu et al., 2013) and stimulation of BDNF production (Marosi and Mattson, 2014). In addition, during IER levels of insulin, IGF-1, and proinflammatory hormones (leptin) and cytokines (TNF, IL-1 $\beta$, etc.) are reduced, and production of anti-inflammatory hormones (ghrelin and adiponectin) and cytokines (IL-10) is increased (Johnson et al., 2007; Longo and Mattson, 2014). Together with brain-autonomous responses to fasting and hunger, such changes in circulating factors during fasting likely contribute to some of the beneficial effects of energy restriction on brain function and resistance to injury, stress, and disease as summarized in the next three paragraphs.

When rats are subjected to IER, their activity level increases during both the fasting and feeding days compared with their baseline activity during ad libitum feeding (Fig. 4A). However, when on the IER diet, activity in the light period begins to increase several hours earlier during fasting days compared with feeding days. Body temperature is reduced on fasting days and returns to the baseline level on feeding days (Fig. 4B). Long-term IER results in improved performance of mice on a range of cognitive tasks, which is associated with morphological evidence of enhanced hippocampal plasticity (Li et al., 2013). BDNF levels are increased in brain regions involved in cognition, motivation, and sensory and motor behaviors in response to IER (Arumugam et al., 2010). BDNF is known to play important roles in synaptic plasticity and neurogenesis, consistent with its involvement in the increased synaptic density and neurogenesis that occur in the hippocampus in response to dietary energy restriction (Lee et al., 2002; Stranahan et al., 2009). Interestingly, mitochondrial biogenesis plays essential roles in the formation and maintenance of hippocampal synapses and the ability of BDNF to promote synaptogenesis (Cheng et al., 2012). The latter findings suggest the possibility that exercise and IER can increase the number of mitochondria in neurons, although this remains to be established.

By activating multiple adaptive cellular stress response pathways, IER can protect CNS and peripheral neurons against dysfunction and degeneration in a range of animal models. IER increases the resistance of hippocampal pyramidal neurons and striatal medium spiny neurons to degeneration induced by the neurotoxins kainic acid and 3-nitropropionic acid in rat models relevant to temporal lobe epilepsy and Huntington's disease, respectively (Bruce-Keller et al., 1999). IER also protects dopaminergic neurons and preserves motor function in a mitochondrial toxin-based model of Parkinson's disease (Duan and Mattson, 1999), and is also beneficial in gene mutation-based models of Alzheimer's (Halagappa et al., 2007), Huntington's (Duan et al., 2003), and Charcot-Marie-Tooth (Madorsky et al., 2009) diseases. In addition, energy restriction can protect the brain and spinal cord against acute traumatic and ischemic injury (Davis et al., 2008; Arumugam et al., 2010; Jeong et al., 2011), perhaps by bolstering neurotrophic signaling, antioxidant defenses, protein chaperones, autophagy, and DNA repair (Longo and Mattson, 2014). For example, IER in mice results in increased levels of fibroblast growth factor 2, heme oxygenase 1 (an antioxidant enzyme), and the protein chaperones HSP70 and GRP78 in the cerebral cortex and striatum (Arumugam et al., 2010). In peripheral nerves, IER upregulates autophagy, which may protect cells against the deleterious effects of mitochondrial dysfunction (Madorsky et al., 2009).

Although findings from studies of animal models demonstrate numerous beneficial effects of IER on brain function and resistance to injury and disease, evidence that similar effects occur in humans is limited. It is well known that sleepiness typically occurs after eating a meal, thereby reducing alertness and cognitive performance (Zammit et al., 1992). Foregoing breakfast and/or lunch can therefore improve productivity, not only by increasing the time available to work, but also by promoting sustained cognitive function while working. Indeed, one myth regarding eating patterns is that it is important to eat at least three meals each day; "otherwise, you will not have enough energy to work or exercise." Indeed, compared with glucose, the ketones produced during fasting provide a more robust and steady energy substrate for neurons, and experimental elevation of $\beta$-hydroxybutyrate levels can improve cognitive function in subjects with Type 1 diabetes, and mild cognitive impairment or early Alzheimer's disease (Page et al., 2009). Moreover, dietary energy restriction resulted in improved verbal memory during a 3 month period in normal elderly human subjects (Witte et al., 2009). The possible effects of IER on cognitive function, neuronal network activity, and brain neurotrophic factor signaling remain to be determined.

\section{Future directions}

An abundance of questions remain to be answered concerning how exercise and IER affect the functionality, durability, and resilience of the brain. For instance, most animal studies of exercise have focused on voluntary wheel running. What are the types, intensity, duration, and frequency of exercise that promote optimal neuroplasticity and cognitive function in humans? Which neuronal circuits are active during running and other exercises, and during fasting? Is the activity in those neurons critical for the enhancement of neuroplasticity? Are there neuronal activity-independent mechanisms involved in the beneficial effects of exercise and IER on the brain? Do exercise and IER produce similar or distinct changes in central stress-responsive neurocircuitry? In addition to ketone bodies, are there other factors produced in peripheral tissues that mediate effects of exercise and IER on the brain? Are there muscle-derived factors that mediate beneficial effects of exercise on the brain? Recent findings suggest that, indeed, exercise induces release of the protein irisin from muscle cells, and circulating irisin can induce BDNF expression in hippocampal neurons (Wrann et al., 2013). Is irisin release from exercising muscle, the critical "muscle to brain" signal proposed to affect stress-responsive neural circuitry? Such a concept is consistent with evidence that activation of AMPK in muscle cells (which occurs during exercise) can enhance spatial learning and memory and motor performance in young mice (Kobilo et al., 2011a) and aged mice, and that it also increases the expression of genes important for synaptic plasticity in the hippocampus (Kobilo et al., 2014). If and how do astrocytes and microglia respond to exercise, and do glial cells contribute to exerciseinduced enhancement of synaptic plasticity and neurogenesis? Is the cerebral vasculature affected by exercise and IER and, if so, by what mechanisms? Recent findings have shown that running increases vascular density in the hippocampus (Pereira et al., 2007), but to what extent this angiogenesis is critical for effects of exercise on brain function and disease resistance remains to be determined. Another fundamental question relevant to the ongoing epidemics of obesity, diabetes, and associated diseases concerns the relative contributions of activation of disease processes by overindulgent sedentary 
A

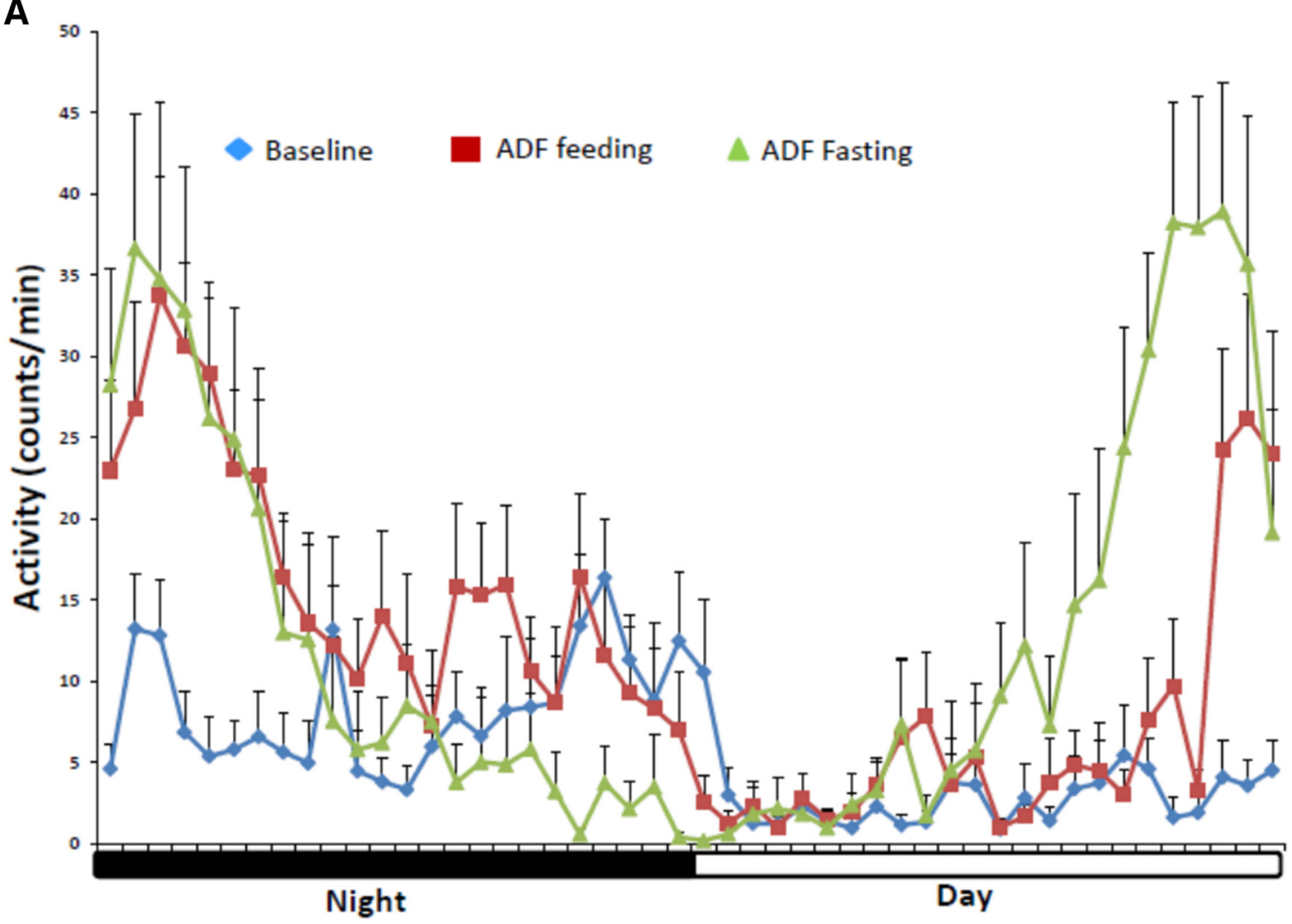

B

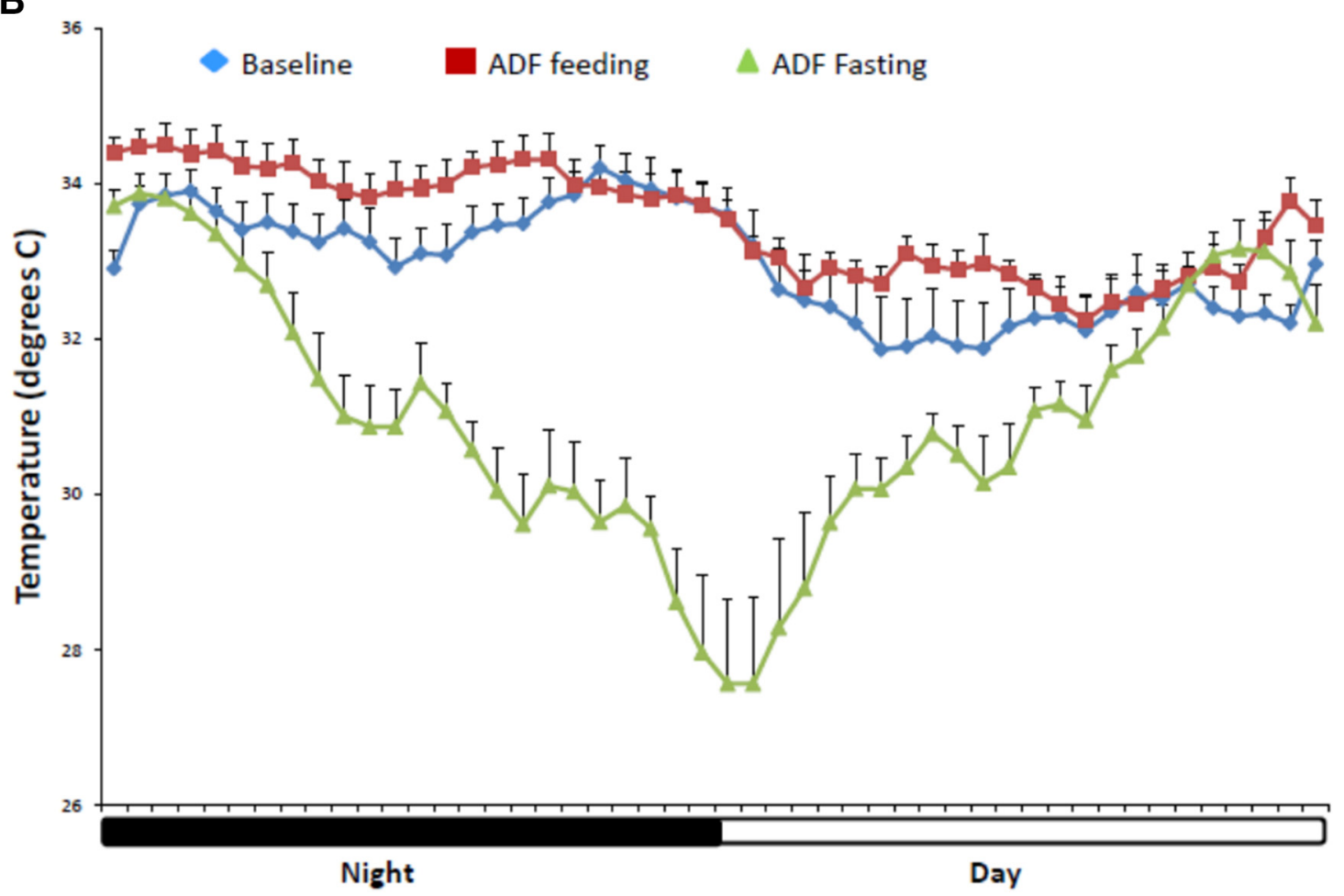

Figure 4. Alternate day fasting (ADF) increases activity levels and reduces body temperature in rats. Young adult male Sprague Dawley rats were implanted with transmitters to enable continuous recording of activity and body temperature in the home cage. After recording activity and temperature on the usual ad libitum diet (baseline), the rats were maintained on an ADF diet for 2 months. Examples of $24 \mathrm{~h}$ recordings of activity $(\boldsymbol{A})$ and body temperature $(\boldsymbol{B})$ from one rat are shown at baseline, on a feeding day and on a fasting day; food was either removed or supplied at 16:00 $\mathrm{h}$, which was $2 \mathrm{~h}$ before the start of the dark period. Overall activity is greater in both the dark and light periods when the rats are on the ADF diet compared with baseline, and that during the fasting day there is a robust increase in activity beginning $\sim 2 \mathrm{~h}$ before feeding time. Values are mean $\pm \operatorname{SEM}(n=6$ rats). 
lifestyles versus lack of activation of the adaptive stress response pathways engaged by exercise and IER.

Animals in the wild and hominid hunter-gatherers are often most physically active when motivated by hunger. Studies of how fasting affects the brain's responses to exercise, and the impact of exercise on peripheral energy metabolism, may inform approaches for improving brain function and overall health. In rodents, dietary energy restriction and running can have additive effects on synaptic plasticity and BDNF levels (Stranahan et al., 2009), suggesting that conditions that demanded optimal brain function during evolution may also promote optimal brain function in modern humans. In support of the latter possibility, studies have shown that memory is improved when encoding occurs during exercise (SchmidtKassow et al., 2013) and that regular aerobic exercise can improve cognitive performance in individuals at risk for $\mathrm{AD}$, including insulin-resistant elderly subjects (Baker et al., 2010). It will be of considerable interest to determine whether IER also improves cognitive function in humans and whether combining IER with exercise can further bolster brain function and protect against cognitive impairment during aging.

Although challenging the brain and body intermittently through physical exercise and energy restriction is beneficial for overall health and brain health, there has been no concerted effort in our society to enable and implement such energetic challenge-based daily and weekly routines. The results of human studies suggest that many people can adapt to and even thrive on regular exercise and IER-based eating patterns (Cao et al., 2009; Harvie et al., 2011). However, a period of $\sim 1$ month is required for the body and brain to adapt to vigorous exercise and IER programs, particularly for those who have previously been sedentary and eating three meals/ day plus snacks. A society-wide effort will be required to implement "brain and body health" programs in the educational and health care systems, communities, and workplaces. In this regard, there are several major impediments to achieving the latter goal, including the agriculture, processed/fast food, and pharmaceutical industries. The omnipresence of caloriereplete processed foods and advances in technologies that eliminate the need to exercise have infiltrated societies and are widely promoted in advertisements. Moreover, as a result of promotion by the pharmaceutical industry and relative lack of training in medical education, doctors generally do not rigorously pursue exercise- and diet-based prescriptions and, instead, prescribe drugs even at early stages of diseases (obesity, diabetes, cardiovascular disease), which could be safely and effectively reversed/cured by exercise and IER. The emerging evidence that exercise and IER can improve and sustain brain functionality, and may protect against neurodegenerative disorders, provides a rationale for widespread dissemination of this take-home message.

\section{References}

Alirezaei M, Kemball CC, Flynn CT, Wood MR, Whitton JL, Kiosses WB (2010) Short-term fasting induces profound neuronal autophagy. Autophagy 6:702-710. CrossRef Medline

Amaral DG, Witter MP (1989) The three-dimensional organization of the hippocampal formation: a review of anatomical data. Neuroscience 31 : 571-591. CrossRef Medline

Amat J, Matus-Amat P, Watkins LR, Maier SF (1998) Escapable and inescapable stress differentially alter extracellular levels of 5-HT in the basolateral amygdala of the rat. Brain Res 812:113-120. CrossRef Medline

Amat J, Baratta MV, Paul E, Bland ST, Watkins LR, Maier SF (2005) Medial prefrontal cortex determines how stressor controllability affects behavior and dorsal raphe nucleus. Nat Neurosci 8:365-371. CrossRef Medline
Amat J, Paul E, Zarza C, Watkins LR, Maier SF (2006) Previous experience with behavioral control over stress blocks the behavioral and dorsal raphe nucleus activating effects of later uncontrollable stress: role of the ventral medial prefrontal cortex. J Neurosci 26:13264-13272. CrossRef Medline

Arumugam TV, Phillips TM, Cheng A, Morrell CH, Mattson MP, Wan R (2010) Age and energy intake interact to modify cell stress pathways and stroke outcome. Ann Neurol 67:41-52. CrossRef Medline

Baker LD, Frank LL, Foster-Schubert K, Green PS, Wilkinson CW, McTiernan A, Cholerton BA, Plymate SR, Fishel MA, Watson GS, Duncan GE, Mehta PD, Craft S (2010) Aerobic exercise improves cognition for older adults with glucose intolerance, a risk factor for Alzheimer's disease. J Alzheimers Dis 22:569-579. CrossRef Medline

Baratta MV, Lucero TR, Amat J, Watkins LR, Maier SF (2008) Role of the ventral medial prefrontal cortex in mediating behavioral control-induced reduction of later conditioned fear. Learn Mem 15:84-87. CrossRef Medline

Bekinschtein P, Oomen CA, Saksida LM, Bussey TJ (2011) Effects of environmental enrichment and voluntary exercise on neurogenesis, learning and memory, and pattern separation: BDNF as a critical variable? Semin Cell Dev Biol 22:536-542. CrossRef Medline

Bernard C (1854) Leçons de Ohysiologie Experimentale Applique's à la Medecine. Paris: Bailliere.

Best JD, Kahn SE, Ader M, Watanabe RM, Ni TC, Bergman RN (1996) Role of glucose effectiveness in the determination of glucose tolerance. Diabetes Care 19:1018-1030. Medline

Boschloo L, Reeuwijk KG, Schoevers RA, Pennix WJHB (2014) The impact of lifestyle factors on the 2-year course of depressive and/or anxiety disorders. J Affect Disord 159:73-79. CrossRef Medline

Bramble DM, Lieberman DE (2004) Endurance running and the evolution of Homo. Nature 432:345-352. CrossRef Medline

Brown JD, Siegel JM (1988) Exercise as a buffer of life stress: a prospective study of adolescent health. Health Psychol 7:341-353. CrossRef Medline

Bruce-Keller AJ, Umberger G, McFall R, Mattson MP (1999) Food restriction reduces brain damage and improves behavioral outcome following excitotoxic and metabolic insults. Ann Neurol 45:8-15. CrossRef Medline

Cai D (2012) One step from prediabetes to diabetes: hypothalamic inflammation? Endocrinology 153:1010-1013. CrossRef Medline

Campeau S, Nyhuis TJ, Sasse SK, Kryskow EM, Herlihy L, Masini CV, Babb JA, Greenwood BN, Fleshner M, Day HE (2010) Hypothalamic pituitary adrenal axis responses to low-intensity stressors are reduced after voluntary wheel running in rats. J Neuroendocrinol 22:872-888. CrossRef Medline

Cao ZB, Tabata I, Nishizono H (2009) Good maintenance of physical benefits in a 12-month exercise and nutritional intervention by voluntary, home-based exercise: a 6-month follow-up of a randomized controlled trial. J Bone Miner Metab 27:182-189. CrossRef Medline

Cheng A, Wan R, Yang JL, Kamimura N, Son TG, Ouyang X, Luo Y, Okun E, Mattson MP (2012) Involvement of PGC- $1 \alpha$ in the formation and maintenance of neuronal dendritic spines. Nat Commun 3:1250. CrossRef Medline

Chiarreotto-Ropelle EC, Pauli LS, Katashima CK, Pimentel GD, Picardi PK, Silva VR, de Souza CT, Prada PO, Cintra DE, Carvalheira JB, Ropelle ER, Pauli JR (2013) Acute exercise suppresses hypothalamic PTP1B protein level and improves insulin and leptin signaling in obese rats. Am J Physiol Endocrinol Metab 305:E649-E659. CrossRef Medline

Clark PJ, Brzezinska WJ, Thomas MW, Ryzhenko NA, Toshkov SA, Rhodes JS (2008) Intact neurogenesis is required for benefits of exercise on spatial memory but not motor performance or contextual fear conditioning in C57BL/6J mice. Neuroscience 155:1048-1058. CrossRef Medline

Clelland CD, Choi M, Romberg C, Clemenson GD Jr, Fragniere A, Tyers P, Jessberger S, Saksida LM, Barker RA, Gage FH, Bussey TJ (2009) A functional role for adult hippocampal neurogenesis in spatial pattern separation. Science 325:210-213. CrossRef Medline

Creer DJ, Romberg C, Saksida LM, van Praag H, Bussey TJ (2010) Running enhances spatial pattern separation in mice. Proc Natl Acad Sci U S A 107:2367-2372. CrossRef Medline

da Silva AA, Tallam LS, Liu J, Hall JE (2006) Chronic antidiabetic and cardiovascular actions of leptin: role of CNS and increased adrenergic activity. Am J Physiol Regul Integr Comp Physiol 291:R1275-R1282. CrossRef Medline

Davis LM, Pauly JR, Readnower RD, Rho JM, Sullivan PG (2008) Fasting is 
neuroprotective following traumatic brain injury. J Neurosci Res 86: 1812-1822. CrossRef Medline

Day HE, Greenwood BN, Hammack SE, Watkins LR, Fleshner M, Maier SF, Campeau S (2004) Differential expression of 5HT-1A, alpha 1b adrenergic, CRF-R1, and CRF-R2 receptor mRNA in serotonergic, gammaaminobutyric acidergic, and catecholaminergic cells of the rat dorsal raphe nucleus. J Comp Neurol 474:364-378. CrossRef Medline

Dezfulian C, Garrett M, Gonzalez NR (2013) Clinical application of preconditioning and postconditioning to achieve neuroprotection. Transl Stroke Res 4:19-24. CrossRef Medline

Duan W, Mattson MP (1999) Dietary restriction and 2-deoxyglucose administration improve behavioral outcome and reduce degeneration of dopaminergic neurons in models of Parkinson's disease. J Neurosci Res 57:195-206. CrossRef Medline

Duan W, Guo Z, Jiang H, Ware M, Li XJ, Mattson MP (2003) Dietary restriction normalizes glucose metabolism and BDNF levels, slows disease progression, and increases survival in huntingtin mutant mice. Proc Natl Acad Sci U S A 100:2911-2916. CrossRef Medline

Duman CH, Schlesinger L, Russell DS, Duman RS (2008) Voluntary exercise produces antidepressant and anxiolytic behavioral effects in mice. Brain Res 1199:148-158. CrossRef Medline

Fleshner M (2000) Exercise and neuroendocrine regulation of antibody production: protective effect of physical activity on stress-induced suppression of the specific antibody response. Int J Sports Med 21 [Suppl 1]:S14-S19.

Fleshner M (2005) Physical activity and stress resistance: sympathetic nervous system adaptations prevent stress-induced immunosuppression. Exerc Sport Sci Rev 33:120-126. CrossRef Medline

Fleshner M, Maier SF, Lyons DM, Raskind MA (2011) The neurobiology of the stress-resistant brain. Stress 14:498-502. CrossRef Medline

Fleshner M, Thompson RS, Greenwood BN (2013) Impact of physical activity on diurnal rhythms: a potential mechanisms for stress resistance or stress resilience. In: The handbook of physical activity and mental health. New York: Routledge.

Foley TE, Fleshner M (2008) Neuroplasticity of dopamine circuits after exercise: implications for central fatigue. Neuromolecular Med 10:67-80. CrossRef Medline

German JP, Thaler JP, Wisse BE, Oh IS, Sarruf DA, Matsen ME, Fischer JD, Taborsky GJ Jr, Schwartz MW, Morton GJ (2011) Leptin activates a novel CNS mechanism for insulin-independent normalization of severe diabetic hyperglycemia. Endocrinology 152:394-404. CrossRef Medline

Greenwood BN, Fleshner M (2008) Exercise, learned helplessness, and the stress-resistant brain. Neuromolecular Med 10:81-98. CrossRef Medline

Greenwood BN, Fleshner M (2011) Exercise, stress resistance, and central serotonergic systems. Exerc Sport Sci Rev 39:140-149. CrossRef Medline

Greenwood BN, Kennedy S, Smith TP, Campeau S, Day HE, Fleshner M (2003a) Voluntary freewheel running selectively modulates catecholamine content in peripheral tissue and c-Fos expression in the central sympathetic circuit following exposure to uncontrollable stress in rats. Neuroscience 120:269-281. CrossRef Medline

Greenwood BN, Foley TE, Day HE, Campisi J, Hammack SH, Campeau S, Maier SF, Fleshner M (2003b) Freewheel running prevents learned helplessness/behavioral depression: role of dorsal raphe serotonergic neurons. J Neurosci 23:2889-2898. Medline

Greenwood BN, Foley TE, Burhans D, Maier SF, Fleshner M (2005) The consequences of uncontrollable stress are sensitive to duration of prior wheel running. Brain Res 1033:164-178. CrossRef Medline

Greenwood BN, Foley TE, Le TV, Strong PV, Loughridge AB, Day HE, Fleshner M (2011) Long-term voluntary wheel running is rewarding and produces plasticity in the mesolimbic reward pathway. Behav Brain Res 217: 354-362. CrossRef Medline

Greenwood BN, Loughridge AB, Sadaoui N, Christianson JP, Fleshner M (2012a) The protective effects of voluntary exercise against the behavioral consequences of uncontrollable stress persist despite an increase in anxiety following forced cessation of exercise. Behav Brain Res 233:314321. CrossRef Medline

Greenwood BN, Strong PV, Loughridge AB, Day HE, Clark PJ, Mika A, Hellwinkel JE, Spence KG, Fleshner M (2012b) 5-HT(2C) receptors in the basolateral amygdala and dorsal striatum are a novel target for the anxiolytic and antidepressant effects of exercise. PLoS One 7:e46118. CrossRef Medline

Greenwood BN, Spence KG, Crevling DM, Clark PJ, Craig WC, Fleshner M (2013) Exercise-induced stress resistance is independent of exercise con- trollability and the medial prefrontal cortex. Eur J Neurosci 37:469-478. CrossRef Medline

Grégoire CA, Bonenfant D, Le Nguyen A, Aumont A, Fernandes KJ (2014) Untangling the influences of voluntary running, environmental complexity, social housing and stress on adult hippocampal neurogenesis. PLoS One 9:e86237. CrossRef Medline

Halagappa VK, Guo Z, Pearson M, Matsuoka Y, Cutler RG, Laferla FM, Mattson MP (2007) Intermittent fasting and caloric restriction ameliorate age-related behavioral deficits in the triple-transgenic mouse model of Alzheimer's disease. Neurobiol Dis 26:212-220. CrossRef Medline

Hardie DG (2004) The AMP-activated protein kinase pathway: new players upstream and downstream. J Cell Sci 117:5479-5487. CrossRef Medline

Harvie MN, Pegington M, Mattson MP, Frystyk J, Dillon B, Evans G, Cuzick J, Jebb SA, Martin B, Cutler RG, Son TG, Maudsley S, Carlson OD, Egan JM, Flyvbjerg A, Howell A (2011) The effects of intermittent or continuous energy restriction on weight loss and metabolic disease risk markers: a randomized trial in young overweight women. J Obes (Lond) 35:714727. CrossRef Medline

Havel PJ, Uriu-Hare JY, Liu T, Stanhope KL, Stern JS, Keen CL, Ahrén B (1998) Marked and rapid decreases of circulating leptin in streptozotocin diabetic rats: reversal by insulin. Am J Physiol 274:R1482-R1491. Medline

Horvath TL, Sarman B, García-Cáceres C, Enriori PJ, Sotonyi P, Shanabrough M, Borok E, Argente J, Chowen JA, Perez-Tilve D, Pfluger PT, Brönneke HS, Levin BE, Diano S, Cowley MA, Tschöp MH (2010) Synaptic input organization of the melanocortin system predicts dietinduced hypothalamic reactive gliosis and obesity. Proc Natl Acad Sci U S A 107:14875-14880. CrossRef Medline

Jeong MA, Plunet W, Streijger F, Lee JH, Plemel JR, Park S, Lam CK, Liu J, Tetzlaff W (2011) Intermittent fasting improves functional recovery after rat thoracic contusion spinal cord injury. J Neurotrauma 28:479-492. CrossRef Medline

Johnson JB, Summer W, Cutler RG, Martin B, Hyun DH, Dixit VD, Pearson M, Nassar M, Telljohan R, Maudsley S, Carlson O, John S, Laub DR, Mattson MP (2007) Alternate day calorie restriction improves clinical findings and reduces markers of oxidative stress and inflammation in overweight adults with moderate asthma. Free Radic Biol Med 42:665674. CrossRef Medline

Kahn SE, Cooper ME, Del Prato S (2014) Pathophysiology and treatment of type 2 diabetes: perspectives on the past, present, and future. Lancet 383: 1068-1083. CrossRef Medline

Kennedy SL, Smith TP, Fleshner M (2005) Resting cellular and physiological effects of freewheel running. Med Sci Sports Exerc 37:79-83. CrossRef Medline

Kobilo T, Yuan C, van Praag H (2011a) Endurance factors improve hippocampal neurogenesis and spatial memory in mice. Learn Mem 18:103107. CrossRef Medline

Kobilo T, Liu QR, Gandhi K, Mughal M, Shaham Y, van Praag H (2011b) Running is the neurogenic and neurotrophic stimulus in environmental enrichment. Learn Mem 18:605-609. CrossRef Medline

Kobilo T, Guerrieri D, Zhang Y, Collica SC, Becker KG, van Praag H (2014) AMPK agonist AICAR improves cognition and motor coordination in young and aged mice. Learn Mem 21:119-126. CrossRef Medline

Krawczewski Carhuatanta KA, Demuro G, Tschöp MH, Pfluger PT, Benoit SC, Obici S (2011) Voluntary exercise improves high-fat diet-induced leptin resistance independent of adiposity. Endocrinology 152:26552664. CrossRef Medline

Kuhla B, Kuhla S, Rudolph PE, Albrecht D, Metges CC (2007) Proteomics analysis of hypothalamic response to energy restriction in dairy cows. Proteomics 7:3602-3617. CrossRef Medline

Lee J, Duan W, Mattson MP (2002) Evidence that brain-derived neurotrophic factor is required for basal neurogenesis and mediates, in part, the enhancement of neurogenesis by dietary restriction in the hippocampus of adult mice. J Neurochem 82:1367-1375. CrossRef Medline

Lett BT, Grant VL, Byrne MJ, Koh MT (2000) Pairings of a distinctive chamber with the aftereffect of wheel running produce conditioned place preference. Appetite 34:87-94. CrossRef Medline

Lett BT, Grant VL, Koh MT (2001) Naloxone attenuates the conditioned place preference induced by wheel running in rats. Physiol Behav 72:355358. CrossRef Medline

Li L, Wang Z, Zuo Z (2013) Chronic intermittent fasting improves cognitive functions and brain structures in mice. PLoS One 8:e66069. CrossRef Medline 
Li Y, Luikart BW, Birnbaum S, Chen J, Kwon CH, Kernie SG, Bassel-Duby R, Parada LF (2008) TrkB regulates hippocampal neurogenesis and governs sensitivity to antidepressive treatment. Neuron 59:399-412. CrossRef Medline

Longo VD, Mattson MP (2014) Fasting: molecular mechanisms and clinical applications. Cell Metab 19:181-192. CrossRef Medline

Loughridge AB, Greenwood BN, Day HE, McQueen MB, Fleshner M (2013) Microarray analyses reveal novel targets of exercise-induced stress resistance in the dorsal raphe nucleus. Front Behav Neurosci 7:37. CrossRef Medline

Lu M, Wan M, Leavens KF, Chu Q, Monks BR, Fernandez S, Ahima RS, Ueki K, Kahn CR, Birnbaum MJ (2012) Insulin regulates liver metabolism in vivo in the absence of hepatic Akt and Foxol. Nat Med 18:388-395. CrossRef Medline

Madorsky I, Opalach K, Waber A, Verrier JD, Solmo C, Foster T, Dunn WA Jr, Notterpek L (2009) Intermittent fasting alleviates the neuropathic phenotype in a mouse model of Charcot-Marie-Tooth disease. Neurobiol Dis 34:146-154. CrossRef Medline

Maier SF, Watkins LR (2010) Role of the medial prefrontal cortex in coping and resilience. Brain Res 1355:52-60. CrossRef Medline

Marosi K, Mattson MP (2014) BDNF mediates adaptive brain and body responses to energetic challenges. Trends Endocrinol Metab 25:89-98. CrossRef Medline

Marr D (1971) Simple memory: a theory for archicortex. Philos Trans R Soc Lond B Biol Sci 262:23-81. CrossRef Medline

Mattson MP (2012) Exercise and energy intake as determinants of brain health and vulnerability to injury and disease. Cell Metab 16:706-722.

Meijer JH, Robbers Y (2014) Wheel running in the wild. Proc Biol Soc 281: 1786. CrossRef Medline

Milanski M, Arruda AP, Coope A, Ignacio-Souza LM, Nunez CE, Roman EA, Romanatto T, Pascoal LB, Caricilli AM, Torsoni MA, Prada PO, Saad MJ, Velloso LA (2012) Inhibition of hypothalamic inflammation reverses diet-induced insulin resistance in the liver. Diabetes 61:1455-1462. CrossRef Medline

Moraska A, Fleshner M (2001) Voluntary physical activity prevents stressinduced behavioral depression and anti-KLH antibody suppression. Am J Physiol Regul Integr Comp Physiol 281:R484-R489. Medline

Morris RG, Garrud P, Rawlins JN, O’Keefe J (1982) Place navigation impaired in rats with hippocampal lesions. Nature 24:681-683. CrossRef Medline

Morton GJ, Matsen ME, Bracy DP, Meek TH, Nguyen HT, Stefanovski D, Bergman RN, Wasserman DH, Schwartz MW (2013) FGF19 action in the brain induces insulin-independent glucose lowering. J Clin Invest 123:4799-4808. CrossRef Medline

Mustroph ML, Chen S, Desai SC, Cay EB, DeYoung EK, Rhodes JS (2012) Aerobic exercise is the critical variable in an enriched environment that increases hippocampal neurogenesis and water maze learning in male C57BL/6J mice. Neuroscience 219:62-71. CrossRef Medline

Nakagawa T, Tsuchida A, Itakura Y, Nonomura T, Ono M, Hirota F, Inoue T, Nakayama C, Taiji M, Noguchi H (2000) Brain-derived neurotrophic factor regulates glucose metabolism by modulating energy balance in diabetic mice. Diabetes 49:436-444. CrossRef Medline

Narkar VA, Downes M, Yu RT, Embler E, Wang YX, Banayo E, Mihaylova MM, Nelson MC, Zou Y, Juguilon H, Kang H, Shaw RJ, Evans RM (2008) AMPK and PPAR $\delta$ agonists are exercise mimetics. Cell 134:405-415. CrossRef Medline

Neeper SA, Gómez-Pinilla F, Choi J, Cotman C (1995) Exercise and brain neurotrophins. Nature 373:109. CrossRef Medline

O'Neill HM (2013) AMPK and exercise: glucose uptake and insulin sensitivity. Diabetes Metab J 37:1-21. CrossRef Medline

Page KA, Williamson A, Yu N, McNay EC, Dzuira J, McCrimmon RJ, Sherwin RS (2009) Medium-chain fatty acids improve cognitive function in intensively treated type 1 diabetic patients and support in vitro synaptic transmission during acute hypoglycemia. Diabetes 58:1237-1244. CrossRef Medline

Pereira AC, Huddleston DE, Brickman AM, Sosunov AA, Hen R, McKhann GM, Sloan R, Gage FH, Brown TR, Small SA (2007) An in vivo correlate of exercise-induced neurogenesis in the adult dentate gyrus. Proc Natl Acad Sci U S A 104:5638-5643. CrossRef Medline

Philippas NG, Lo CW (2005) Childhood obesity: etiology, prevention, and treatment. Nutr Clin Care 8:77-88. Medline

Pi-Sunyer X (2009) The medical risks of obesity. Postgrad Med 121:21-33. CrossRef Medline
Posey KA, Clegg DJ, Printz RL, Byun J, Morton GJ, Vivekanandan-Giri A, Pennathur S, Baskin DG, Heinecke JW, Woods SC, Schwartz MW, Niswender KD (2009) Hypothalamic proinflammatory lipid accumulation, inflammation, and insulin resistance in rats fed a high-fat diet. Am J Physiol Endocrinol Metab 296:E1003-E1012. CrossRef Medline

Sahay A, Scobie KN, Hill AS, O'Carroll CM, Kheirbek MA, Burghardt NS, Fenton AA, Dranovsky A, Hen R (2011) Increasing adult hippocampal neurogenesis is sufficient to improve pattern separation. Nature 472:466470. CrossRef Medline

Sasse SK, Greenwood BN, Masini CV, Nyhuis TJ, Fleshner M, Day HE, Campeau S (2008) Chronic voluntary wheel running facilitates corticosterone response habituation to repeated audiogenic stress exposure in male rats. Stress 11:425-437. CrossRef Medline

Schmidt-Kassow M, Deusser M, Thiel C, Otterbein S, Montag C, Reuter M, Banzer W, Kaiser J (2013) Physical exercise during encoding improves vocabulary learning in young female adults: a neuroendocrinological study. PLoS One 8:e64172. CrossRef Medline

Schwartz MW, Seeley RJ, Tschöp MH, Woods SC, Morton GJ, Myers MG, D’Alessio D (2013) Cooperation between brain and islet in glucose homeostasis and diabetes. Nature 503:59-66. CrossRef Medline

Shimazu T, Hirschey MD, Newman J, He W, Shirakawa K, Le Moan N, Grueter CA, Lim H, Saunders LR, Stevens RD, Newgard CB, Farese RV Jr, de Cabo R, Ulrich S, Akassoglou K, Verdin E (2013) Suppression of oxidative stress by $\beta$-hydroxybutyrate, an endogenous histone deacetylase inhibitor. Science 339:211-214. CrossRef Medline

Speaker KJ, Cox SS, Paton MM, Serebrakian A, Maslanik T, Greenwood BN, Fleshner M (2014) Six weeks of voluntary wheel running modulates inflammatory protein (MCP-1, IL-6, and IL-10) and DAMP (Hsp72) responses to acute stress in white adipose tissue of lean rats. Brain Behav Immun 39:87-98. CrossRef Medline

Stranahan AM, Lee K, Martin B, Maudsley S, Golden E, Cutler RG, Mattson MP (2009) Voluntary exercise and caloric restriction enhance hippocampal dendritic spine density and BDNF levels in diabetic mice. Hippocampus 19:951-961. CrossRef Medline

Stranahan AM, Lee K, Becker KG, Zhang Y, Maudsley S, Martin B, Cutler RG, Mattson MP (2010) Hippocampal gene expression patterns underlying the enhancement of memory by running in aged mice. Neurobiol Aging 31:1937-1949. CrossRef Medline

Strong PV, Greenwood BN, Fleshner M (2009) The effects of the selective 5-HT(2C) receptor antagonist SB 242084 on learned helplessness in male Fischer 344 rats. Psychopharmacology (Berl) 203:665-675. CrossRef Medline

Strong PV, Christianson JP, Loughridge AB, Amat J, Maier SF, Fleshner M, Greenwood BN (2011) 5-Hydroxytryptamine 2C receptors in the dorsal striatum mediate stress-induced interference with negatively reinforced instrumental escape behavior. Neuroscience 197:132-144. CrossRef Medline

Taupin P (2007) Adult neural stem cells: The promise of the future. Neuropsychiatr Dis Treat. 3:753-760.

Thaler JP, Yi CX, Schur EA, Guyenet SJ, Hwang BH, Dietrich MO, Zhao X, Sarruf DA, Izgur V, Maravilla KR, Nguyen HT, Fischer JD, Matsen ME, Wisse BE, Morton GJ, Horvath TL, Baskin DG, Tschöp MH, Schwartz MW (2012) Obesity is associated with hypothalamic injury in rodents and humans. J Clin Invest 122:153-162. CrossRef Medline

Thompson RS, Strong PV, Clark PJ, Maslanik TM, Wright KP Jr, Greenwood BN, Fleshner M (2014) Repeated fear-induced diurnal rhythm disruptions predict PTSD-like sensitized physiological acute stress responses in F344 rats. Acta Physiol 211:447-465. CrossRef Medline

Tong L, Shen H, Perreau VM, Balazs R, Cotman CW (2001) Effects of exercise on gene-expression profile in the rat hippocampus. Neurobiol Dis 8:1046-1056. CrossRef Medline

van Praag H (2008) Neurogenesis and exercise: past and future directions. Neuromolecular Med 10:128-140. CrossRef Medline

Vivar C, Potter MC, Choi J, Lee JY, Stringer TP, Callaway EM, Gage FH, Suh $\mathrm{H}$, van Praag H (2012) Monosynaptic inputs to new neurons in the dentate gyrus. Nat Commun 3:1107. doi: 10.1038/ncomms2101. CrossRef Medline

Vivar C, Potter MC, van Praag H (2013) All about running: synaptic plasticity, growth factors and adult hippocampal neurogenesis. Curr Top Behav Neurosci 15:189-210. CrossRef Medline

Voss MW, Vivar C, Kramer AF, van Praag H (2013) Bridging animal and human models of exercise-induced brain plasticity. Trends Cogn Sci 17: 525-544. CrossRef Medline

Wan R, Weigand LA, Bateman R, Griffioen K, Mendelowitz D, Mattson MP 
(2014) Evidence that BDNF regulates heart rate by a mechanism involving increased brainstem parasympathetic neuron excitability. J Neurochem 129:573-580. CrossRef Medline

Wang YX, Zhang CL, Yu RT, Cho HK, Nelson MC, Bayuga-Ocampo CR, Ham J, Kang H, Evans RM (2004) Regulation of muscle fiber type and running endurance by PPAR $\delta$. PLoS Biol 2:e294. CrossRef Medline

Witte AV, Fobker M, Gellner R, Knecht S, Flöel A (2009) Caloric restriction improves memory in elderly humans. Proc Natl Acad Sci U S A 106:12551260. CrossRef Medline

Wrann CD, White JP, Salogiannnis J, Laznik-Bogoslavski D, Wu J, Ma D, Lin JD, Greenberg ME, Spiegelman BM (2013) Exercise induces hippocampal BDNF through a PGC-1 $\alpha$ /FNDC5 pathway. Cell Metab 18:649-659. CrossRef Medline
Xu X, Zhan M, Duan W, Prabhu V, Brenneman R, Wood W, Firman J, Li H, Zhang P, Ibe C, Zonderman AB, Longo DL, Poosala S, Becker KG, Mattson MP (2007) Gene expression atlas of the mouse central nervous system: impact and interactions of age, energy intake and gender. Genome Biol 8:R234. CrossRef Medline

Yang JL, Lin YT, Chuang PC, Bohr VA, Mattson MP (2014) BDNF and exercise enhance neuronal DNA repair by stimulating CREB-mediated production of apurinic/apyrimidinic endonuclease 1. Neuromolecular Med 16:161-174. CrossRef Medline

Zammit GK, Ackerman SH, Shindledecker R, Fauci M, Smith GP (1992) Postprandial sleep and thermogenesis in normal men. Physiol Behav 52: 251-259. CrossRef Medline 